\title{
28. CHROMIAN SPINELS IN LEG 49 BASALTS: A PRELIMINARY CHEMICAL STUDY
}

\author{
J.A. Templeman, Department of Mineralogy, British Museum (Natural History), London U.K.
}

\section{INTRODUCTION}

Ten samples of basalt have been made available to us for study, of which four, from Holes 411 and 413 , contain chromian spinel. The spinels occur as small octahedral inclusions in olivine and plagioclase, or more rarely as discrete crystals in the groundmass. They range from 0.01 to $0.05 \mathrm{~mm}$ in size, and from translucent red-brown to yellow-brown in color.

Analyses of the host olivines show a $\mathrm{CaO}$ content of approximately 0.3 per cent in each case, which has been used by Graham et al. (1978) to differentiate between olivines crystallized from a basaltic liquid $(\mathrm{CaO} \sim 0.3 \%)$ and those from an ultramafic source $(\mathrm{CaO} \sim 0.06 \%)$. That the olivines and enclosed spinels appear to be in equilibrium indicates that both olivines and enclosed spinels have crystallized from their basaltic host liquid.

\section{RESULTS AND DISCUSSION}

Whole-rock and spinel analyses are given in Tables 1 and 2 ; analyses of silicates coexisting with the spinels are in Table 3 . The spinels and coexisting phases were analyzed using the Geoscan microprobe at the British Museum (Natural History), and the Energy Dispersive System at Cambridge.

TABLE 1

Whole-Rock Compositions of SpinelBearing Basalts From Leg 49

\begin{tabular}{lrrr}
\hline & $1^{\mathrm{a}}$ & \multicolumn{1}{c}{$2^{\mathrm{b}}$} & \multicolumn{1}{c}{$3^{\mathrm{c}}$} \\
\hline $\mathrm{SiO}_{2}$ & 48.23 & 47.66 & 47.48 \\
$\mathrm{TiO}_{2}$ & 0.70 & 1.37 & 0.70 \\
$\mathrm{Al}_{2} \mathrm{O}_{3}$ & 15.11 & 14.19 & 16.26 \\
$\mathrm{Fe}_{2} \mathrm{O}_{3}{ }^{*}$ & 10.18 & 10.43 & 11.06 \\
$\mathrm{MnO}_{\mathrm{MgO}}$ & 0.17 & 0.18 & 0.16 \\
$\mathrm{CaO}_{\mathrm{Na}} \mathrm{O}$ & 11.38 & 9.32 & 10.51 \\
$\mathrm{~K}_{2} \mathrm{O}$ & 11.71 & 12.15 & 10.88 \\
$\mathrm{H}_{2} \mathrm{O}^{+}$ & 1.75 & 1.96 & 2.44 \\
$\mathrm{H}_{2} \mathrm{O}^{-}$ & 0.44 & 0.79 & 1.36 \\
$\mathrm{CO}_{2}$ & 0.61 & 1.15 & - \\
$\mathrm{P}_{2} \mathrm{O}_{5}$ & 0.12 & 0.05 & - \\
$\mathrm{Total}_{\mathrm{Cr}}$ & 0.06 & 0.20 & 0.08 \\
\hline $\mathrm{apm})$ & 284 & 257 & n.d. \\
\hline
\end{tabular}

a Sample 411-2-1, 138-40 cm.

${ }^{\mathrm{b}}$ Sample 413-2-1, 46-50 cm.

${ }^{c}$ Sample 413-5-1, $45-50 \mathrm{~cm}$. Analyst:

D. Wood. Analysis unavailable for

Sample 411-3-1, 96-100 cm.

$\mathrm{d}_{\mathrm{n} . \mathrm{d} .}=$ not determined.
Six elements - Fe, Mn, Cr, Ti, Al, Mg - were determined for the spinels and these, together with $\mathrm{Ca}, \mathrm{Si}$, and $\mathrm{Na}$, were determined for the silicate phases. Mn values obtained on the Geoscan are almost certainly too high, owing to the inability of probe to resolve the $\mathrm{MnK} \alpha$ peak from the $\mathrm{CrK} \alpha$ peak at low Mn levels. For this reason, the $\mathrm{Mn}$ values obtained on the Cambridge probe have been taken as more reliable, and an average of these Mn values has been used to calculate the cation sitochiometry for the Geoscan samples. Stoichiometric proportions of cations were calculated on the basis of 32 oxygens, and ions were apportioned in such a way that the sum of the $2+$ ions, including $\mathrm{Fe}^{2+}$, was equal to one-third the total number of cations. The remaining ion can then be taken as $\mathrm{Fe}^{3+}$.

The small grain size of the spinels precluded detection of any compositional zoning.

The spinel analyses have been plotted (Figure 1) on the $(\mathrm{Cr} / \mathrm{Cr}+\mathrm{Al}) /(\mathrm{Mg} / \mathrm{Mg}+\mathrm{Fe})$ face of the spinel compositional prism (Irvine, 1965), along with the approximate "chromian spinel" and "magnesiochromite" fields of Sigurdsson and Schilling (1976). The only analyses which cannot be classified as magnesiochromites are the two spinels from Section 413-2-1, which, showing a high $\mathrm{Cr} / \mathrm{Cr}+\mathrm{Al}$ ratio and over 0.5 per cent $\mathrm{TiO}_{2}$, can be termed "titaniferous magnesiochromites,' as defined by Sigurdsson and Schilling (1976). The rest plot across the lower part of the magnesiochromite field.

It can be seen that, for all samples except 411-3-1, and two small spinels from $411-2-1$, the $\mathrm{Cr} / \mathrm{Cr}+\mathrm{Al}$ ratio tends to be constant, with change only in the $\mathrm{Mg} / \mathrm{Mg}+\mathrm{Fe}$ ratio. These changes can be ascribed to reaction of the initially $\mathrm{Mg}$-rich spinels with an increasing $\mathrm{Fe}^{2+}$-rich residual liquid. Considering the four analyses from Section 411-2-1 joined by tie lines, it can be seen that those spinels enclosed in an early-formed phase, such as olivine, have remained more $\mathrm{Mg}$-rich than those enclosed in feldspar or occurring free in the liquid.

Conditions within the cooling rock have obviously favored the reaction of $2+$ ions rather than $3+$ ions, but it remains to be determined whether the constancy of the $\mathrm{Cr} / \mathrm{Cr}+\mathrm{Al}$ ratio is a result of a reaction of a constant proportion of $\mathrm{Cr}$ and $\mathrm{Al}$ with $\mathrm{Fe}^{3+}$, or whether no reaction has occurred at all. Henderson (1975) distinguishes two distinct trends in the Rhum spinels (Figure 2): an "Al-trend," which involves a marked change in $\mathrm{Cr} / \mathrm{Cr}+\mathrm{Al}$ ratio, and an "Fe-trend," which produces a change in $\mathrm{Fe}^{3+}$ with constant $\mathrm{Cr} / \mathrm{Al}+\mathrm{Cr}$ ratio. It might be expected that, with their constancy of $\mathrm{Cr} / \mathrm{Cr}+\mathrm{Al}$ ratio, the Leg 49 spinels would show an "Fe-trend," but this cannot be established from the few available results presented here (Figure 3 ).

It would therefore appear, from the results so far obtained, that thermodynamic conditions within the melt 
TABLE 2

Spinel Compositions

\begin{tabular}{|c|c|c|c|c|c|c|c|c|c|c|c|c|c|}
\hline & 1 & 2 & 3 & 4 & 5 & 6 & 7 & 8 & 9 & 10 & 11 & 12 & 13 \\
\hline $\mathrm{NiO}$ & - & - & 0.23 & 0.18 & - & 0.18 & - & 0.20 & - & - & - & - & - \\
\hline $\mathrm{FeO}^{*}$ & 17.04 & 18.53 & 16.36 & 18.77 & 21.60 & 21.11 & 17.02 & 17.79 & 20.36 & 22.36 & 16.42 & 16.73 & 18.91 \\
\hline $\mathrm{MnO}$ & $0.83^{\mathrm{a}}$ & $0.84^{\mathrm{a}}$ & 0.20 & 0.34 & 0.40 & 0.42 & 0.46 & 0.41 & $0.78^{\mathrm{a}}$ & $0.81^{\mathrm{a}}$ & 0.24 & 0.22 & 0.25 \\
\hline $\mathrm{Cr}_{2} \mathrm{O}_{3}$ & 34.38 & 33.75 & 32.19 & 32.89 & 36.20 & 33.72 & 34.50 & 34.20 & 41.76 & 42.96 & 34.29 & 32.82 & 32.62 \\
\hline $\mathrm{TiO}_{2}$ & 0.34 & 0.38 & 0.26 & 0.29 & 0.28 & 0.46 & 0.24 & 0.26 & 1.43 & 1.48 & 0.34 & 0.30 & 0.32 \\
\hline $\mathrm{CaO}$ & - & - & - & - & 0.64 & 0.17 & 0.11 & 0.14 & - & - & - & - & - \\
\hline $\mathrm{SiO}_{2}$ & - & - & - & - & 1.92 & 0.39 & 0.17 & 0.34 & - & - & - & - & - \\
\hline $\mathrm{Al}_{2} \mathrm{O}_{3}$ & 31.09 & 30.69 & 29.78 & 31.47 & 26.39 & 29.89 & 30.86 & 31.84 & 18.66 & 19.04 & 29.96 & 31.18 & 30.09 \\
\hline $\mathrm{MgO}$ & 16.10 & 13.99 & 19.11 & 15.37 & 12.45 & 13.67 & 16.19 & 16.15 & 13.43 & 12.21 & 15.38 & 15.53 & 13.97 \\
\hline Total & 99.48 & 98.18 & 98.13 & 99.31 & 100.36 & 100.01 & 99.55 & 101.33 & 96.42 & 98.86 & 96.63 & 96.78 & 96.16 \\
\hline \multicolumn{14}{|c|}{ Number of Cations (32 ' 0 ') } \\
\hline $\mathrm{Ti}^{4+}$ & 0.06 & 0.07 & 0.05 & 0.05 & 0.05 & 0.08 & 0.04 & 0.05 & 0.28 & 0.29 & 0.06 & 0.05 & 0.06 \\
\hline $\mathrm{Al}^{3+}$ & 8.70 & 8.80 & 8.41 & 8.86 & 7.86 & 8.54 & 8.64 & 8.79 & 5.77 & 5.79 & 8.62 & 8.92 & 8.78 \\
\hline $\mathrm{Cr}^{3+}$ & 6.46 & 6.49 & 6.10 & 6.21 & 7.24 & 6.46 & 6.49 & 6.34 & 8.66 & 8.77 & 6.62 & 6.30 & 6.39 \\
\hline $\mathrm{Fe}^{3+}$ & 1.01 & 0.81 & 1.91 & 1.15 & 1.11 & 1.18 & 1.09 & 1.08 & 1.62 & 1.45 & 0.90 & 0.95 & 1.01 \\
\hline $\mathrm{Fe}^{2+}$ & 2.37 & 2.96 & 1.36 & 2.60 & 3.35 & 3.10 & 2.30 & 2.40 & 2.86 & 3.38 & 2.45 & 2.44 & 2.92 \\
\hline $\mathrm{Mn}^{2+}$ & 0.05 & 0.05 & 0.04 & 0.07 & 0.08 & 0.09 & 0.04 & 0.08 & 0.06 & 0.06 & 0.05 & 0.04 & 0.05 \\
\hline $\mathrm{Mg}^{2+}$ & 5.70 & 5.08 & 6.83 & 5.47 & 4.69 & 4.94 & 5.74 & 5.64 & 5.25 & 4.70 & 5.60 & 5.62 & 5.16 \\
\hline
\end{tabular}

Note: $1-8=$ spinels from $411-2-1 ; 9,10=$ spinels from $413-2-1 ; 11,12=$ spinels from $411-3-1 ; 13=$ spinels from $413-5-1$.

${ }^{\mathrm{a}} \mathrm{High} \mathrm{MnO}$ probably caused by $\mathrm{Cr}_{\mathrm{r}}$ peak interference.

TABLE 3

Analyses of Phases Coexisting With Spinels

\begin{tabular}{lcccccc}
\hline & 1 & 2 & 3 & 4 & 5 & 6 \\
\hline $\mathrm{NiO}$ & 0.17 & 0.22 & n.d. & - & - & 0.22 \\
$\mathrm{FeO}$ & 12.25 & 11.52 & 0.77 & 11.66 & 11.55 & 11.89 \\
$\mathrm{MnO}$ & 0.15 & 0.16 & n.d. & - & - & 0.19 \\
$\mathrm{CaO}$ & 0.40 & 0.31 & 14.83 & 0.30 & 0.30 & 0.31 \\
$\mathrm{SiO}_{2}$ & 40.57 & 40.50 & 50.60 & 41.26 & 40.88 & 40.69 \\
$\mathrm{Al}_{2} \mathrm{O}_{3}$ & 0.72 & - & 30.47 & - & - & - \\
$\mathrm{MgO}$ & 46.52 & 47.61 & 0.30 & 47.97 & 47.52 & 47.62 \\
$\mathrm{Na}_{2} \mathrm{O}$ & n.d. & n.d. & 2.49 & n.d. & n.d. & n.d. \\
& 100.78 & 100.32 & 99.46 & 101.19 & 100.25 & 100.92 \\
\hline
\end{tabular}

Note: 1,2 = olivine coexisting with spinel, $411-2-1 ; 3=$ feldspar coexisting with spinel, $411-2-1 ; 4,5=$ olivine coexisting with spinel, 413-2-1; 6 = olivine coexisting with spinel, 411-2-1. n.d. $=$ not determined $;-=$ not found.

favor the exchange of $2+$ ions in tetrahedral sites over that at $3+$ ions in octahedral sites.

\section{ACKNOWLEDGMENTS}

Thanks are due to D.A. Wood, for the loan of two samples, and to Dr. N. Charnley for the use of the Cambridge microprobe. I would also like to thank Drs. P. Henderson and D.R.C. Kempe for their assistance.

\section{REFERENCES}

Graham, A.L., Symes, R.F., Bevan, J.C., and Din, V.K., 1978. Chromium-bearing spinels in some rocks of Leg 45: Phase chemistry, zoning and relation to host basalt chemistry. In Melson, W. and Rabinowitz, P.O., et al., Initial Reports of the Deep Sea Drilling Project, v. 45: Washington (U.S. Government Printing Office).

Henderson, P., 1975. Reaction trends shown by chrome spinels at the Rhum layered intrusion, Geochim. Cosmochim, Acta, v. 39, p. 1035-1044.

Irvine, T.N., 1965. Chromian spinel as a petrogenetic indicatorpart 1, Theory, Canadian J. Earth Sci., v. 2, p. 648-672.

Sigurdsson, H. and Schilling, J.G., 1976. Spinels in Mid-Atlantic Ridge basalts: chemistry and occurrence, Earth. Planet. Sci. Lett., v. 29 , p. 7-20. 


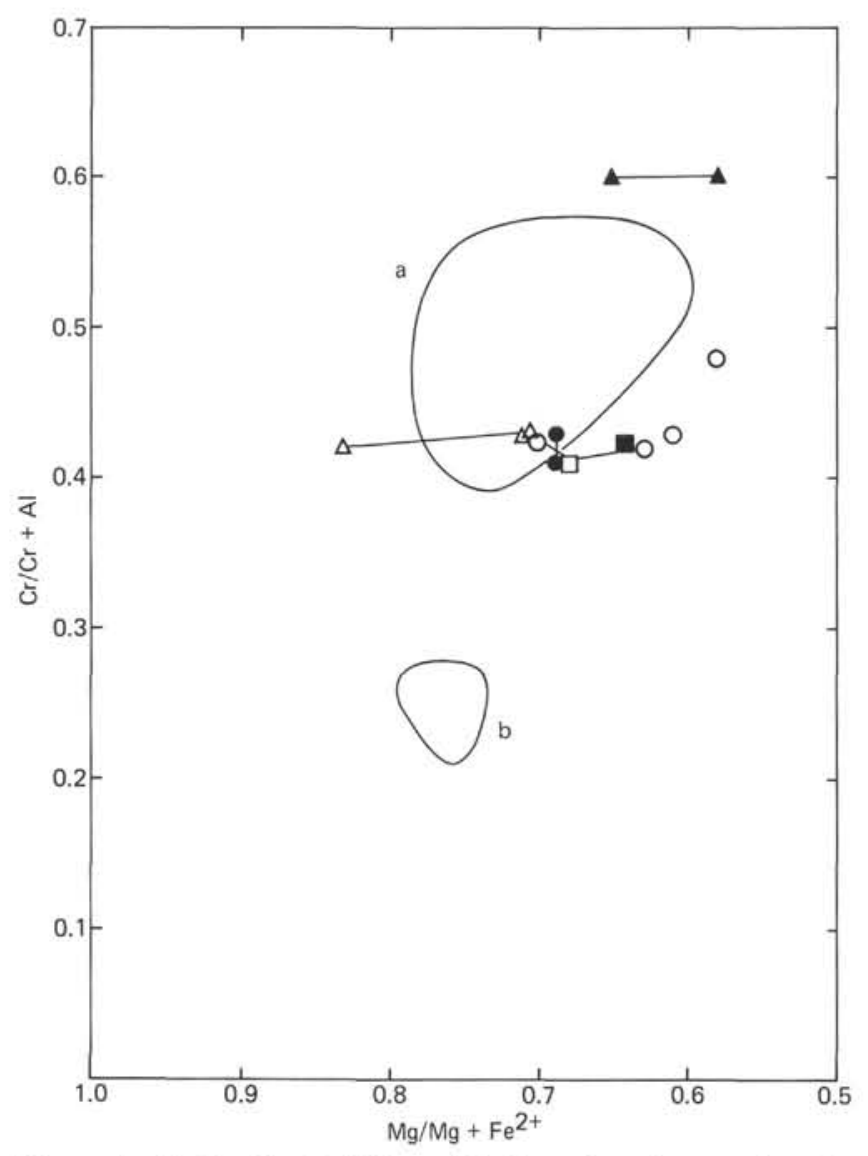

Figure 1. Molecular $\mathrm{Cr} /(\mathrm{Cr}+\mathrm{Al})$ plotted against molecular $\mathrm{Mg} /\left(\mathrm{Mg}+\mathrm{Fe}^{2+}\right)$ for spinels from Leg 49 basalts. Filled triangles-spinels from Sample 413-2-1, 46-50 cm; open triangles, square, circles-spinels from Sample 411-2-1, $138-40 \mathrm{~cm}$, enclosed in olivine, plagioclase, and free in groundmass, respectively; filled circles, spinels from Sample 411-3-1, 96-100 cm; filled square-spinel from Sample 413-5-1, 46-50 cm. Fields marked " $a$ " and " $b$ " represent the approximate magnesiochromite and chromian spinel fields of Sigurdsson and Schilling (1976).

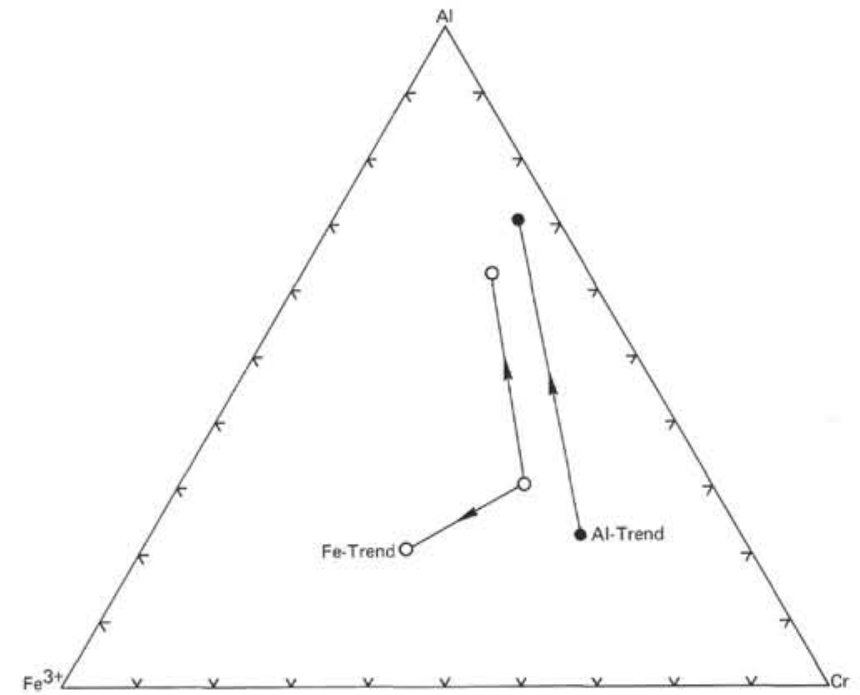

Figure 2. Ternary plot of the molecular proportions of $\mathrm{Y}^{3+}\left(\mathrm{Fe}^{3+}, \mathrm{Al}, \mathrm{Cr}\right)$, showing $\mathrm{Al}$ and $\mathrm{Fe}$-trends, after Henderson (1975). Arrows indicate probable trend direc tions.

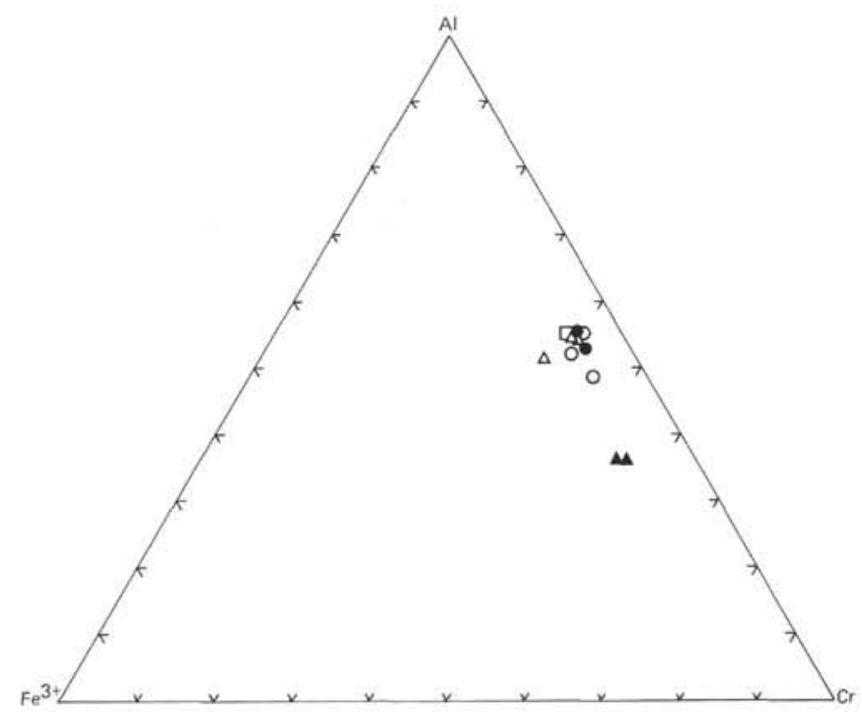

Figure 3. Ternary plot of the molecular proportions of $\mathrm{Y}^{3+}\left(\mathrm{Fe}^{3+}, \mathrm{Al}, \mathrm{Cr}\right)$ in the analyzed spinels. Symbols as for Figure 1. 